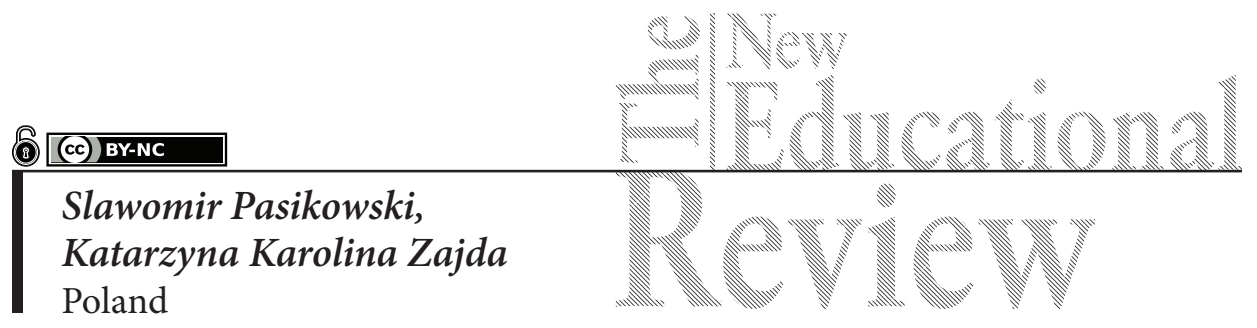

\title{
A Validation of The Inventory of Attitude Toward Social Innovation
}

DOI: 10.15804/tner.2018.53.3.04

\begin{abstract}
The article presents the results of validation studies on the Inventory of Attitudes Towards Social Innovation. The measurement was conducted on public institution employees and members of non-governmental organizations, i.e., people who, due to their professional or social roles, participate in resolving local social problems. The study was conducted using cross-validation. Factor structure, internal consistency of the test and subscales, and stability over time were assessed using the test-retest method. The results indicate a three-factor structure of the phenomenon, as well as satisfactory psychometric properties of the inventory.
\end{abstract}

Keywords: attitudes, social innovation, measurement, validation

\section{Introduction}

The aim of implementing grassroots social innovations is to resolve various social problems of residents of different local areas (Pellicer-Sifres et al., 2017). In the article, these innovations refer to actions, services, and products, previously unavailable in a given area, which constitute an alternative to previous practices in this scope, and the implementation of which is dictated by the need to resolve social problems at a local level (Zajda, Pasikowski, 2018).

The implementation of grassroots social innovations is connected with the introduction of social change in a specific local context (Van Dyck, Van den 
Broeck, 2014; Shier, Handy, 2015). As these actions, services, and products have not yet been used in resolving local social problems, their implementation raises uncertainty and does not have to be successful, which is why the leaders of institutions and organizations willing to implement them are expected to accept this risk (Flemig, Osborne, Kinder, 2014). These leaders can represent various institutions and organizations from the public and social sectors, and (less frequently) from the economic sector. Cooperation between entities (representing different sectors) is perceived as the greatest opportunity for these innovations to be implemented. This requires trust in other entities and in unassociated residents of a given area, who participate in the process of grassroots social innovations implementation (Terstriep et al., 2015, pp. 49-51, 93).

Many public institutions, including the European Commission, support the implementation of social innovations (Jessop et al., 2014, p. 110), e.g., in education. Education is also seen as an opportunity to propagate, implement and popularize social innovations (including grassroots social innovations) (Surikova et al., 2015, p. 238; Jędrych, Szczepańczyk, 2017). Shaping an attitude which fosters the implementation of such innovations is of special significance in former socialist states (such as Poland), where the term social innovation is barely present in public discourse, often being incorrectly associated with economic and organizational innovations, and perceived as an empty slogan used out of necessity in order to obtain means for the realization of various projects connected with resolving social problems (Baran et al., 2016, p.15). Importantly, shaping an attitude which fosters the implementation of grassroots social innovations is possible when we are familiar with this attitude. The aim of this article is to present and assess the authors' own tool for its measurement. Such a tool (to the authors' knowledge) is lacking in Polish and as well as English-language source literature.

It was taken into consideration during the construction of the tool that currently the prevalent position in attitude theory claims that the evaluative element of attitude plays a significant role in its determination (Bohner \& Wanke, 2002; Chaiken \& Stangor, 1987; Fazio, 2007). This element is connected with information on the emotional significance of the attitude object, and its storage in memory, from whence it is recalled through stimuli associated with the remembered experience. Thus, attitude tends to be regarded by some authors as acquired and relatively persistent evaluation of objects (Fazio, 2007). Attitude is expressed through spatial and psychological distance. A positive attitude is indicated when the subject seeks to make contact with the object, while a negative attitude is shown when the subject avoids or distances itself from the object (cf., Cacioppo, Gardner, \& Berntson, 1997; Valacher, Nowak, \& Kaufman, 1994). For this reason, according to the 
above-mentioned definition of attitude as an evaluation of an object, the question concerning distance also makes it possible to encompass that which is treated in older concepts as separate components of attitude, i.e., cognitive, behavioural and affective.

\section{Research Problem}

The main problem on which the study was focused was the identification and description of attitude towards social innovation among people who participate (due to their professional or social roles) in resolving local social problems. For this reason, an instrument to measure this phenomenon was designed and its psychometric properties were assessed.

\section{Research Methodology}

\section{Research General Background}

The validation study design was conducted in the model of cross-validation (Urbina, 2004; Vagias et al., 2012), which consists in dividing a set of data into at least 2 parts, on which a part or all of the analyses in the scope of the test psychometric properties and factor structure determination are repeated. The separated parts were equipotent while observations were randomly assigned. The stability of the test was subject to separate assessment using the test-retest method.

\section{Participants}

The measurement was conducted on employees of public institutions in rural community offices who, due to their professional roles, work on solving local social problems, and on members of local NGOs who were the most active in solving these problems. 101 out of 146 public institutions, i.e., community offices and social welfare centres located in the rural communities of the Łódź and Mazovian Provinces (Poland) were drawn at random. An employee from each of these organisations was selected for the sample. NGOs (foundations, associations, unions of associations) were drawn based on the sampling frame acquired by the Central Statistical Office. In this way, further 139 people were selected to the sample. In total, there were 240 participants, including 179 women and 61 men. The average age of the respondents was 47 years $(\mathrm{m}=47.44, \mathrm{me}=47$, $s \mathrm{~d}=12.14$, As=.20, $\mathrm{K}=-.58$ ). The distribution of education was as follows: third level (higher) education - 114 people, secondary education - 78 people, below secondary education - 48 people. 


\section{Instrument and Procedures}

The entire pool of generated items of the Inventory of Attitudes Towards Social Innovation included 37 elements. It was subject to professional linguistic assessment in the scope of grammatical and substantive accuracy. Then, it was assessed by 5 judges (psychologists, sociologists and pedagogues), who were appointed for this purpose, and who responded to each item in order to determine its adequacy in measuring attitudes towards social innovation. A 5-point rating scale was used to provide answers, where " 1 " meant "completely unsuitable" and " 5 " meant "very well suited". Out of the 37 items, 1 was excluded from further analysis because of its very low general ratings. Agreement among raters was high enough to qualify 36 items for further studies (Kendall's $\mathrm{W}=.592, \mathrm{df}=35, \mathrm{chi}^{2}=103.56, \mathrm{p}=.000$ ).

The instruction to the Inventory of Attitudes Towards Social Innovation includes information that the subject of the study is individual attitude towards issues connected with the occurrence of changes concerning residents of a given area. The task of the respondent was to determine how close (i.e. it arouses a willingness to approach and attracts) he/she finds the issues referred to in each item of the inventory. The answers were to be provided on a 7-point rating scale, where the left extreme was described as "not close to me at all" and the right extreme was described as "very close to me".

The pool of initial items used in the validation study is presented in Table 1. The order of items in the test was established at random.

Table 1. The initial item pool of the Inventory of Attitudes Towards Social Innovation

\begin{tabular}{cl}
\hline $\begin{array}{c}\text { Item } \\
\text { No. }\end{array}$ & \multicolumn{1}{c}{...how close do you find EACH of the issues described in the table below } \\
\hline 1 & implementing unusual methods of dealing with the problems of residents \\
\hline 2 & $\begin{array}{l}\text { looking for solutions which differ from those previously used in dealing with the prob- } \\
\text { lems of residents }\end{array}$ \\
\hline 3 & learning more than is currently required by my role in this AREA \\
\hline 4 & ideas put forward by representatives of organisations and institutions other than mine \\
\hline 5 & looking for ways to deal with the problems of residents \\
\hline 6 & taking risks in making decisions which introduce changes in this AREA \\
\hline 7 & putting my own ideas forward \\
\hline 8 & ideas put forward by residents \\
\hline 9 & projects concerning this AREA, but other than previously undertaken \\
\hline 10 & realizing of my own ideas
\end{tabular}




\begin{tabular}{|c|c|}
\hline $\begin{array}{l}\text { Item } \\
\text { No. }\end{array}$ & ...how close do you find EACH of the issues described in the table below \\
\hline 11 & ideas deviating from the prevailing standards \\
\hline 12 & introducing changes concerning this AREA \\
\hline 13 & people with a worldview different from mine \\
\hline 14 & people who think differently than others \\
\hline 15 & $\begin{array}{l}\text { taking responsibility for the implementation of ideas in this AREA, which diverge from } \\
\text { common practice }\end{array}$ \\
\hline 16 & someone else's ideas which foreshadow changes in the current state of affairs \\
\hline 17 & experiencing stress while implementing untypical ideas authored by other people \\
\hline 18 & $\begin{array}{l}\text { ways of dealing with the problems of residents which differ from those currently } \\
\text { practiced }\end{array}$ \\
\hline 19 & people who want to introduce changes in this AREA \\
\hline 20 & a lot of options when dealing with the problems of residents \\
\hline 21 & implementing ideas in this AREA, which diverge from what is usually practiced \\
\hline 22 & $\begin{array}{l}\text { mistakes in the implementation of untypical ideas which are meant to remedy } \\
\text { the problems of residents }\end{array}$ \\
\hline 23 & $\begin{array}{l}\text { people who encourage the implementation of untypical ideas which diverge from com- } \\
\text { mon standard }\end{array}$ \\
\hline 24 & $\begin{array}{l}\text { working on the implementation of untypical ideas in this AREA, but authored by other } \\
\text { people }\end{array}$ \\
\hline 25 & developed and fixed methods of dealing with the problems of residents \\
\hline 26 & $\begin{array}{l}\text { lack of success in the implementation of untypical ideas, which are to remedy the prob- } \\
\text { lems of residents }\end{array}$ \\
\hline 27 & bypassing procedures in dealing with the problems of residents \\
\hline 28 & realizing untypical ideas in this AREA \\
\hline 29 & using available resources in a way which diverges from typical practice \\
\hline 30 & $\begin{array}{l}\text { people who realize ideas which are risky and different from those previously implement- } \\
\text { ed in this AREA }\end{array}$ \\
\hline 31 & $\begin{array}{l}\text { something different from what currently exists, and which is said to make the lives of } \\
\text { people who live and work here easier }\end{array}$ \\
\hline 32 & $\begin{array}{l}\text { procedures developed by organizations and institutions that are launched when resi- } \\
\text { dents have any problems }\end{array}$ \\
\hline 33 & ideas which someone could have, and which do not even occur to other people \\
\hline 34 & $\begin{array}{l}\text { ideas which are risky and at the same time different from those previously implemented } \\
\text { in this AREA }\end{array}$ \\
\hline 35 & few options when dealing with the problems of residents \\
\hline 36 & devoting one's own time to the realization of untypical ideas authored by other people \\
\hline
\end{tabular}


The randomly selected institutions were contacted by pollsters, who distributed and collected the inventory forms during single visits.

\section{Data Analysis}

The data was subject to internal consistency of test and exploratory factor analysis, carried out with the use of the principal component method successively with Varimax orthogonal rotation and Oblimin rotation. The test-retest method was applied to assess absolute stability. Statistical inference was carried out at a significance level of $\alpha=0.05$.

\section{Research Results}

First, an analysis of the psychometric properties of particular test items was performed. Then, exploratory factor analysis was carried out on a separate set of data to detect latent variables, which could include individual test items. This approach reduces the number of variables, in this case test items, to more general dimensions. This, in turn, reveals the structure of the test. A separate step was taken to assess the consistency of the test and its scales extracted in the course of factor analysis.

\section{Discriminating Power of Items and Internal Consistency of Test}

Assessment of test properties was initiated by an examination of individual item properties. Attention was focused on item-test correlation, and the susceptibility of items to the selection of extreme responses.

The values of discriminating power coefficients were relatively high for most test items. Average value equalled $.47(\mathrm{sd}=.14, \min =.08, \max =.63)$. A distinctly lower value, i.e., less than 0.30 , was found in items $17,26,27$, and 35 . These items were found not to participate in the total correlation occurring among the test items or to display insignificant participation. This is indicated by Cronbach's a value, which increases or remains unchanged when the items are removed. Cronbach's a correlation coefficient is a measure of internal consistency. For the inventory, which consisted of 36 items, this coefficient equalled 0.87 , but .93 after removing those four items.. Conformity and rejection in response to test items were at an acceptable level, as indicated by the value of the coefficient of difficulty (approval). The coefficient takes values between 0 and 1 . In the case of specific items, the closer this value is to 1 , the more it indicates a generalised choice of high values 
on a rating scale by the participants. The average value for the set of collected data was moderate $(\mathrm{m}=.65, \mathrm{sd}=.07, \min =.44, \max =.79)$.

\section{Test Structure and Internal Consistency of Test Scales}

In the case of the initial pool of test items, the use of factor analysis to reduce the number of variables was justified, as indicated by the satisfactory value of the Keiser-Meyer-Olkin coefficient $(\mathrm{KMO}=.88)$, and by the statistically significant result in Bartlett's test of sphericity $\left(\mathrm{chi}^{2}=3003.47, \mathrm{df}=630, \mathrm{p}=.000\right)$, which signify that the correlations in the matrix of results were clearly above 0 . Cattell's scree test indicated the presence of 2 factors. However, according to Kaiser's criterion, an eigenvalue of more than 1 permitted a justified inclusion of at least a three-factor test structure. The eigenvalue of the first, second, and third factors equalled 14.33, 2.22 , and 2.02, respectively.

The MSA (Measure of Sampling Adequacy) coefficient, which measures the adequacy of the selection of individual variables (test items), was over .5 for most test items. This value was lower only for items 26 and 35. The average MSA value, after removing the items which displayed a value of less than .5 , was .87 . This indicates an appropriately high partial correlation for individual test items. Before the factor analysis procedure, all the items with an MSA value $<.5$ were removed. First, the orthogonal method of factor analysis, i.e. Varimax, was applied. Its results - high factor loadings for more than one factor and high intercorrelations between factors - resulted in a second analysis, this time using the Oblimin rotation method, used for oblique factors.

Due to low factor loadings, items $4,13,15,17,27$, and 32 were also removed from the pool. Low parameters with respect to discriminating power and participation in the total correlation of test items, observed in previous analyses, were confirmed in the case of items 17 and 27.

The procedure of test structure assessment was once again conducted on the reduced item pool $(\mathrm{n}=28)$. The Kaiser-Meyer-Olkin correlation coefficient $(\mathrm{KMO}=.90)$ and a statistically significant result in Bartlett's test of sphericity $\left(\mathrm{chi}^{2}=2396.23, \mathrm{df}=378, \mathrm{p}=.000\right)$ were satisfactory. Cattell's scree test once again indicated the presence of 2 factors, and once again, in accordance with Kaiser's criterion, the eigenvalue of more than 1 allowed for a justified inclusion of at least a three-factor test structure. The eigenvalue of the first, second, and third factors equalled 12.57, 2.01, and 1.69, respectively. For each item, the MSA coefficient was over .8 , and its average value equalled .89 . 
Table 2. The results of exploratory factor analysis using the principal component method with Varimax and Oblimin rotation

\begin{tabular}{|c|c|c|c|c|c|c|}
\hline \multirow{3}{*}{ No. } & \multicolumn{3}{|c|}{ Varimax } & \multicolumn{3}{|c|}{ Oblimin } \\
\hline & \multicolumn{3}{|c|}{ Factor } & \multicolumn{3}{|c|}{ Factor } \\
\hline & 1 & 2 & 3 & 1 & 2 & 3 \\
\hline 1 & .530 & .360 & .165 & .518 & -.241 & -.005 \\
\hline 2 & .644 & .137 & .353 & .661 & .063 & .205 \\
\hline 6 & .681 & .103 & .199 & .739 & .088 & .031 \\
\hline 9 & .547 & .449 & .322 & .493 & -.312 & .151 \\
\hline 11 & .680 & .142 & .427 & .689 & .078 & .278 \\
\hline 12 & .607 & .143 & .466 & .597 & .063 & .338 \\
\hline 18 & .682 & .243 & .385 & .679 & -.041 & .216 \\
\hline 20 & .563 & .324 & .241 & .550 & -.181 & .076 \\
\hline 21 & .783 & .248 & .125 & .844 & -.057 & -.097 \\
\hline 22 & .496 & .158 & .119 & .526 & -.031 & -.018 \\
\hline 29 & .572 & .540 & .139 & .537 & -.433 & -.070 \\
\hline 31 & .520 & .399 & .266 & .481 & -.272 & .103 \\
\hline 34 & .615 & .558 & -.008 & .611 & -.463 & -.247 \\
\hline 19 & .211 & .574 & .463 & .051 & -.516 & .374 \\
\hline 23 & .222 & .809 & .264 & .054 & -.802 & .117 \\
\hline 24 & .183 & .826 & .247 & .009 & -.833 & .106 \\
\hline 28 & .465 & .567 & .215 & .393 & -.480 & .036 \\
\hline 30 & .368 & .690 & .069 & .283 & -.661 & -.118 \\
\hline 33 & .253 & .672 & .271 & .116 & -.641 & .137 \\
\hline 36 & .125 & .677 & .176 & -.017 & -.693 & .064 \\
\hline 3 & .236 & .154 & .695 & .120 & -.011 & .684 \\
\hline 5 & .423 & .116 & .586 & .365 & .064 & .521 \\
\hline 7 & .270 & .148 & .799 & .142 & .019 & .791 \\
\hline 8 & .194 & .351 & .652 & .040 & -.245 & .619 \\
\hline 10 & .459 & .075 & .639 & .406 & .126 & .577 \\
\hline 14 & -.022 & .411 & .539 & -.203 & -.383 & .540 \\
\hline 16 & .138 & .410 & .597 & -.027 & -.333 & .564 \\
\hline 25 & .350 & .192 & .539 & .273 & -.046 & .478 \\
\hline$\sum \mathrm{a}^{2}$ after rot. & 6,16 & 5,35 & 4,76 & 9,90 & 8,00 & 7,32 \\
\hline$\% \mathrm{~S}^{2}$ & 22.01 & 19.11 & 16.98 & $44.88^{\star}$ & $7.16^{\star}$ & $6.05^{\star}$ \\
\hline$\% \mathrm{~S}^{2}$ general & & 58.10 & & & 58.10 & \\
\hline
\end{tabular}

$\sum \mathrm{a}^{2}$ after rot. - the sum of squares of factor loadings (communalities) after rotation, $\% \mathrm{~S}^{2}$ - percent of explained variance, ${ }^{\star}$ the value of the sum of squares of factor loadings before rotation. When factors are correlated, establishing general variance is not possible. 
The review of factor loadings for individual test items using different methods of rotation (Table 2) shows definitely similar results. This increases the credibility of test item grouping as part of distinct factors, as well as a three-factor structure as well describing the gathered data. According to the commonly adopted criterion (Hair, Black, Babin, \& Anderson, 2014, p.115) for a sample of 120 observations and statistical inference at the level of $\alpha=0.05$, the loads that were deemed significant were close to 0.5 or higher.

The range of variance of the measurement results explained by the test and its individual factors are satisfactory. Visible differences between rotation methods result from the properties of these methods. The first factor includes 13 items, the second includes 7 items, and the third includes 8 items.

Application of the Oblimin method was justified by the correlation between factors established on a set of 28 test items (factor 1 - factor 2: -.457, factor 1 factor 3: .450, factor 2 - factor 3: -.360) and relatively high factor loadings on items 29 and 34.

Internal consistency of individual scales was assessed using 2 correlational coefficients: Cronbach's $\alpha$ and Spearman-Brown's split-half coefficient. The value of Cronbach's $\alpha$ for the first, second, and third scales was $.924, .890$, and .873 , respectively. In turn, Spearman-Brown's coefficient was $.935, .912, .865$. The properties of particular test items were satisfactory (Table 3 ).

Table 3. Test item properties

\begin{tabular}{cccc}
\hline Factor & Statistics & Items Difficulty & Items Discriminating Power \\
\hline 1 & $\mathrm{~m}$ & .62 & .67 \\
\cline { 2 - 4 } & $\mathrm{sd}$ & .03 & .08 \\
\cline { 2 - 4 } & $\mathrm{min}$ & .57 & .44 \\
\cline { 2 - 4 } & $\mathrm{max}$ & .68 & .68 \\
\cline { 2 - 4 } & $\mathrm{m}$ & .65 & .70 \\
\cline { 2 - 4 } & $\mathrm{sd}$ & .04 & .08 \\
\hline & $\min$ & .60 & .61 \\
\hline 3 & $\max$ & .69 & .82 \\
\cline { 2 - 4 } & $\mathrm{m}$ & .71 & .63 \\
\cline { 2 - 4 } & $\mathrm{sd}$ & .04 & .08 \\
\cline { 2 - 4 } & $\min$ & .65 & .79 \\
\hline & $\max$ & .76 & \\
\hline
\end{tabular}




\begin{tabular}{lccc}
\hline Factor & Statistics & Items Difficulty & Items Discriminating Power \\
\hline whole- & $\mathrm{m}$ & .65 & .64 \\
\cline { 2 - 4 } test & $\mathrm{sd}$ & .05 & .07 \\
\cline { 2 - 4 } & $\mathrm{min}$ & .57 & .44 \\
\cline { 2 - 4 } & $\mathrm{max}$ & .76 & .75 \\
\hline
\end{tabular}

$\mathrm{m}$ - mean, sd - standard deviation, min - the lowest result, max - the highest result

Extracted factors were given the following names: factor 1 - "Attitude towards social change", factor 2 - "Other participants in social change", factor 3 - "Undertaking activity".

\section{Stability of measurement results over time}

Absolute stability was based on the results of repeated measurement of 42 people ( 34 women, 8 men). The first and second measurements were carried out at an interval of 4 weeks. The analysis was conducted using Pearson's linear correlation coefficient, following an assessment of empirical distributions of correlated variables, two-dimensional scatter plots, and after making certain that the assumption concerning equality of means between measurements was fulfilled. There was no basis for rejecting the null hypothesis that at the level of significance of $\alpha=.05$ the distributions of variables do not vary significantly from normal distribution. This hypothesis was tested using the Shapiro-Wilk test.

Table 4. Pearson's linear correlation coefficients for the results of the first and second measurement

\begin{tabular}{ccc}
\hline Factor & $\mathbf{r}$ & $\mathrm{t}(\mathrm{df}=40)$ \\
\hline 1 & .88 & $11.69^{* * *}$ \\
\hline 2 & .79 & $8.09^{* * *}$ \\
\hline 3 & .86 & $10.63^{* * *}$ \\
\hline whole-test & .90 & $12.90^{* * *}$ \\
\hline
\end{tabular}

${ }^{* * *} \mathrm{p}<.0000$

High correlation coefficients (Table 4) confirm absolute stability of the inventory.

\section{Discussion}

In light of the obtained results, attitude towards social innovation is a multi-dimensional construct, and expresses itself in relation to social change, in relation to other participants in social innovation, and in relation to the act of taking action 
directed at social change. The three-factor structure of the inventory requires stating that the semantic similarity between certain test items outside the group representing a different factor is also expressed in factor correlation and factor loading values. This is the case with items 16 and 28. Their removal at this stage of work on the inventory could have a disadvantageous effect on the validity of the tool in the last phase of its preparation. High coefficients of agreement between measurements suggest not only absolute stability of the tool, but also stability of the cognitive constructs connected with the term social change, which are held by the people in the above-described category. However, this requires further study, in which instruments measuring attitude towards social innovation are indispensable.

Further work on the Inventory of Attitudes Towards Social Innovation will consist in criterion validity assessment, i.e., studying the connections between the test measurement results and measurement results obtained from other tools measuring similar variables, as well as beyond-test criteria, such as actual behaviours or their effects. What is also of vital importance is the period of conducting research using the newly created tool, so that it can be deemed suitable for use, in accordance with the characteristics determined above, and in relation to the population of people. This will make it possible to monitor the behaviour of the inventory under new conditions, and to simultaneously control the stability of its factor structure. However, at this point the parameters of the tool look promising.

\section{Conclusions}

As a result of the conducted studies, a three-factor structure of the Inventory of Attitudes Towards Social Innovation was established. The inventory is characterised by satisfactory psychometric properties in the scope of factor validity, internal consistency of each subscale, and stability of test scores over time. Further research is planned in order to determine the stability of the obtained results and to assess criterion validity.

\section{Acknowledgements}

The conclusions reached in this work are based on the findings of a study carried out as part of the project "Local Systems of Social Innovations in Rural Areas" (financed by Grant no. 015/19/D/HS6/00690 from the National Science Centre, Krakow, contract no. UMO-2015/19/D/HS6/00690, decision no. DEC-2015/19/D/HS6/00690). 


\section{References}

Baran, M., Cichocka, E., Maranowski, P. (2016). Rola innowacji społecznych w polskich uczelniach (Role of social innovations in Polish higher education institutions). Prace Naukowe Uniwersytetu Ekonomicznego we Wrocławiu (Research Papers of Wrocław University of Economics), 444, 13-20.

Bohner, G., Wanke, M. (2002). Attitudes and Attitude Change. Hove: Psychology Press.

Cacioppo, J., Gardner, W., Berntson, G. (1997). Beyond Bipolar Conceptualizations and Measures: The Case of Attitudes and Evaluative Space. Personality and Social Psychology Review, 1(1), 3-25.

Chaiken, S., Stangor, C. (1987). Attitudes and attitude change. Annual Review of Psychology, 38, 575-630.

Fazio, R. (2007). Attitudes as Object-Evaluation Associations of Varying Strength. Social Cognition, 25 (5), 603-637.

Flemig S., Osborne S., Kinder T. (2014). Risk Definition and Risk Governance in Social Innovation Processes: A Conceptual Framework. LIPSE Project Working Paper No 4. Retrieved from: http://www.lipse.org/upload/publications/LIPSE\%20WP\%204\%20 Working\%20paper\%20Flemig\%20et\%20al.pdf (24.04.2018).

Hair, J.F., Black, W.C., Babin, B.J., Anderson, R.E. (2014). Mulivariate data analysis. Edinburgh, Harlow, Essex: Pearson Education Limited.

Jędrych, E., Szczepańczyk, M. (2017). O potrzebie innowacji społecznych w kształceniu ustawicznym Polaków (Lifelong Learning) (On the Need for Social Innovations in Poles' Lifelong Learning). Kwartalnik Naukowy Uczelni Vistula / Vistula Scientific Quarterly, 1(51), 69-81.

Jessop, B., Moulaert F, Hulgård, L., Hamdouch, A., (2014). Social innovation research: a new stage in innovation analysis. In: Moulaert, F., MacCallum, D., Mehmood, A., Hamdouch A (eds.), The International Handbook on Social Innovation, UK, USA: Edward Elgar.

Pellicer-Sifres, V., Belda-Miquel, S., López-Fogués, A., Boni Aristizábal, A. (2017). Grassroots Social Innovation for Human Development: An Analysis of Alternative Food Networks in the City of Valencia (Spain). Journal of Human Development and Capabilities, 18 (2), 258-274.

Shier, M., Handy, F. (2015). From Advocacy to Social Innovation: A Typology of Social Change Efforts by Nonprofits. Voluntas, 26, 2581-2603.

Surikova, S., Oganisjana, K., Grinberga-Zalite, G. (2015). The Role of Education in Promoting Social Innovation Processes in the Society, Rēzeknes Augstskola. Society, Integration, Education, IV, 233-243.

Terstriep, J., Kleverbeck, M., Deserti, A., Rizzo, F. (2015). Comparative Report on Social Innovation across Europe. Deliverable D3.2 of the project «Boosting the Impact of SI in Europe through Economic Underpinnings» (SIMPACT). European Commission - $7^{\text {th }}$ Framework Programme. Brussels: European Commission, DG Research \& Innovation. Urbina, S. (2004). Essentials of Psychological Testing. New Jersey: John Willey \& Sons. Vagias, W.M., Powell, R.B., Moore, D.D., \& Wright, B.A. (2012). Development, Psychometric 
Qualities, and Cross-Validation of the Leave No Trace Attitudinal Inventory and Measure (LNT AIM). Journal of Leisure Research, 44 (2), 234-256.

Valacher, R.R., Nowak, A., Kaufman, J. (1994). Society and self: The emergence of collective properties in self-structure. Journal of Personality and Social Psychology, 67 (1), 20-34. Van Dyck, B., Van den Broeck, P. (2014). Social innovation: a territorial process. In: Moulaert, F., MacCallum, D., Mehmood, A., Hamdouch, A. (eds.), The International Handbook on Social Innovation. UK, USA: Edward Elgar.

Zajda, K., Pasikowski, S. (2018). Individual characteristics of non-governmental organization leaders and the organizations' readiness to implement social innovations. Prace Naukowe Uniwersytetu Ekonomicznego we Wrocławiu (Research Papers of Wrocław University of Economics), 510, 207-216.. 